\title{
Business Models Dynamics and Business Ecosystems in the Emerging 3D Printing Industry
}

\section{Abstract:}

This paper explores the relationships that exist between business models and ecosystems evolving in the 3D printing industry using qualitative evidence drawn from three countries: China, UK and USA. In particular, this research proposes that it is important to understand the process of business model dynamics and formulation and how the associated ecosystem evolves alongside this process to support its development. In studying the dynamics of business models in the 3D printing sector, this research identifies a three-stage process, 'initiation', 'execution' and 'extension', and suggests three capabilities that enable the development of the model, namely, 'scalability', 'flexibility' and 'extensibility'. In addition, it is suggested that the structure of the business ecosystem (product based, platform based, or some combination) influences the potential impact that these capabilities can have on business model development. These findings have implications for those organisations seeking to develop business models and ecosystems around emerging technologies, for practitioners involved in the development and extension of business models, and for academics seeking to evaluate policy and practice within this field.

\section{Keywords:}

Business Model Dynamics, 3D Printing, Business Ecosystems, Capabilities, Platform 


\section{Introduction}

The 3D printing industry has become one of the most promising technologies to underpin the evolution of current manufacturing systems and related supply chains (Petrovic et al., 2011; Berman, 2012). The sector, however, is still at an early stage of formation and profitable business models, supportive ecosystems and associated stakeholders are yet to be clearly identified(Liu and Rong, 2015). This article investigates the dynamics of business model development in the 3D printing sector, the contribution made to such models by the evolving business ecosystem, and the capabilities that facilitate interaction between business models and related ecosystems.

The emerging potential of the 3D printing industry, as a replacement for current mass production processes (West and Kuk, 2016), is derived from its ability to deliver greater customization and flexibility. However, the new technology faces several key challenges. Notably, market demand is uncertain, as the adoption of the technology has been slow and restricted to prototypes for high-end goods in specific sectors, such as healthcare and education. In addition, Further, limited capacity is currently limited also an issue-due to the prohibitive cost of machines and production, the availability of suitable materials, and the narrow product range currently feasible. This latter point, though thisis of aless significancet issue while the en-market demand for 3D outputs remains weak (Sandström, 2015; West and Kuk, 2016). As a consequence, profitable business models around 3D printing have yet to be established.

Similar market challenges have been encountered in many emerging industries and these were normally overcome by encouraging stakeholders within an 
ecosystem to work together to create and evolve effective supply chains and profitable business models (Phaal et al., 2004; Viswanadham and Samvedi, 2013; Rong et al., 2015b; Inoue and Tsujimoto, 2017). Similarly, a attractive industry, 3D printing industry has also drawn a large number of stakeholders that are evolving into a strong business ecosystem capable of

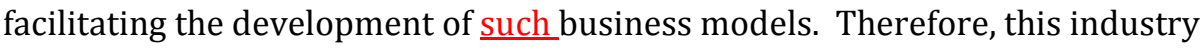
has become a rich data source that could help to demonstrate how business models evolve and the role played by business ecosystems in their development. A business model, while centred on a focal firm, has a scope that reaches beyond the firm to offer a more holistic explanation of how firms 'do business' to create and appropriate value (Amit and Zott, 2001; Zott and Amit, 2007; Spector, 2011; Baden-Fuller and Haefliger, 2013); the concept has become increasingly popular as it is associated with the ability of organisations to develop and sustain competitive advantage (Johnson et al., 2008). However, the literature appertaining to business models has its historic antecedents in a variety of subjects - information technology, strategy, organisational development, innovation and entrepreneurship - and this fragmentation has led to problems of definition (Osterwalder et al., 2005; Teece, 2010). In particular, the extant literature has failed to distinguish between the concept of the business model and the notion of strategy (Hacklin and Wallnofer, 2012). This paper takes the perspective that a business model $_{2}$ is dynamic in nature ${ }_{2}$ which creates a context within which future strategy can be designed and existing strategy operationalised (Casadesus-Masanell and Ricart, 2010; Dahan et al.; 2010; Demil and Lecocq, 2010; van Putten and Schief, 2012). In this context, a business model is the outcome of an aggregated set of relevant activities of a company, 
which take place and evolve out of the ecosystem in which the firm operates. The model describes how marketable information, products and/or services are generated by means of a company's value-added component. However, the extant literature has failed to address certain questions that refer to the role of business models in organisational performance. While considerable information is available on the sources of value creation and how sources interact to enable value appropriation (Amit and Zott, 2001; Zott and Amit, 2007), few analyseis haves been undertaken on the process by which these sources evolve to successfully commercialised technology or how they adapt to exogenous change (Chesbrough and Rosenbloom, 2002; Osterwalder et al., 2005; Morris, Schindehutte and Allen, 2005). We suggest that reaching a point where a business model can demonstrate value creation and value appropriation is the culmination of an iterative process that evolves out of an interaction between stakeholders within an ecosystem. Therefore, ifas research is to support the development and sustainability of business models, there is a need to understand how the determinants of business model performance evolve within relevant ecosystems.

A business ecosystem forms the context in which a business model evolves and is defined as an inter-dependent community including direct partners, universities, government and NGOs, who co-evolve and share similar fates (Moore, 1993; Iansiti and Levien, 2004; Adner and Kapoor, 2010; Gawer and Cusumano, 2014; Rong et al., 2015a; de Vasconcelos Gomes et al., 2016). The business ecosystem approach (Moore, 2006; Liu and Rong, 2015; Rong et al., 2015b, 2010) was proposed to initiate, identify and integrate stakeholders to build value within a system. This value is appropriated from some exchange between two or more 
interdependent groups, usually consumers and producers, through a dynamic framework normally identified as a business model.

As indicated there is limited information available on the process by which business models evolve or the role played by business ecosystems in supporting the creation and appropriation of value. The emerging 3D printing sector provides a suitable context to study the process of building business models and to consider the contribution made by the business ecosystem. Using evidence obtained from seven case studies, this paper provides a critical appraisal of the processes by which business models are developing in the 3D printing sector, as well as the contribution that the business ecosystem has made in forming this development. The process follows three key stages - initiation, execution and extension - where business model development can be underpinned by ecosystem support. Within these stages the research suggests that certain capabilities, namely, scalability, flexibility and extensibility, foster and facilitate the outcomes of interactions between the business ecosystem and the business model.

The reminder of this paper is organized as follows. Section 2 explores the literature appertaining to business models and business ecosystems followed by an investigation on how such concepts cross-over and interact. The approach taken is then discussed followed by a theory building section. The final section of the paper provides a discussion on the theoretical and practical contribution that the paper makes to the literature and identifies opportunities for future research. 


\section{How Ecosystems Support Business Model development: A}

\section{process view}

There are four market opportunities that are currently being considered within the 3D printing sector: the manufacture of 3D printers, a manufacturing service provider-using 3D printers, the design of models employed in the 3D printing process and the provision of material used in the production process. These market opportunities can be divided into two types of business ecosystem. Firstly, a product based ecosystem (with a supply driven business model), in which manufactures sell high value, high margin units of 3D printers at low volumes to end-users; for example the Stratasys, 3D system. Secondly, a platform based ecosystem (Zhu and Iansiti, 2012; Gawer and Cusumano, 2014) which provides a manufacturing service through the effective organisation of 3D printer manufacturers, material providers, designers and customers. These are represented in Figure 1 which identifies a 5M business ecosystem structure, the network it forms and the potential network effects it creates between stakeholders (Zhu and Iansiti 2012, Gawer and Cusumano 2014). The ecosystems identified have the potential to foster and facilitate the development of business models but, as highlighted, market demand, in terms of type and number of customers, is not well understand and this undermines any investment in capacity/supply. An opportunity exists, therefore to explore further how the business model and the ecosystem interact to build value creation and appropriation. 
Insert Figure 1 here

The business model construct is a relatively new unit of analysis which lacks an agreed definition in the literature(Zott et al., 2011), due to its historic antecedents being framed in a variety of subjects (Osterwalder and Pigneur, 2010; Teece, 2010). Despite differences over definition, there is reasonable agreement that the construct is different from notions of product, firm, industry, or network and that focal firms form the hub of the model, around which, other organisations interact. As such athe business model has boundaries that stretch beyond the focal firm and highlights how the interaction of a variety of organisations interact to explain how firms 'do business' to deliver value creation and appropriation (Zott and Amit, 2010). The extant literature has focused upon detailing the outcomes of this dynamic process and the factors that underpin value creation and value appropriation (Amit and Zott, 2001; Zott and Amit, 2007; Baden-Fuller and Haefliger, 2013). While extant research helps to understand why an existing model works (Chesbrough, 2010; Sanchez and Ricart, 2010), it offers limited understanding of the complex interplay of elements and stakeholders that has enabled the business model to reach this position (Demil and Lecocq, 2010) or how this relates to the strategy of the firm (Hacklin and Wallnöfer, 2012).

Recent literature has suggested that a business model creates a context within which future strategy can be designed and existing strategy operationalised (Casadesus-Masanell and Ricart, 2010; Dahan et al., 2010). This notion that a model can design future strategy identifies the dynamic nature of the process 
and the model through adaption (Casadesus-Masanell and Ricart, 2010;

Cavalcante et al., 2011; Demil and Lecocq, 2010; van Putten and Schief, 2013).

As such, the business model is developed out of a series of activities between the firm and relevant stakeholders within an ecosystem. This is often an exploratory process that relies upon trial and error to identify models that support value creation and appropriation. In addition, to the architecture of value creation, strategic $_{2}$ as well as-customer and market components are taken into consideration, which helps to secure competitive advantage. This challenge becomes more difficult in complex and fast-moving environments that are uncertain. In such contexts McGrath (2010) argues that business model strategies are as much about insight, rapid experimentation and evolutionary learning as they are about traditional planning and implementation skills.

This is germane to contexts where new technologies are evolving like 3D printing. New technologies create uncertain contexts where market forces have shifted creating opportunities for the development of new business models. McGrath (2010) argues that dynamic contexts like this lead to resource allocation decisions being made at a time when the environment is uncertain and the components of the business model are not fully understood. Given the uncertainty about how such forces might affect the future workings of a potential business model, it is more sensible for firms to engage in experimentation and discovery, thereby advancing the business model incrementally over time.

This paper suggests that business models evolve from interactions within the appropriate ecosystem. These dynamic and organic groupings change and develop to foster the value creation and capture attributes of a business model as 
it evolves. It is important to understand this complex interplay of factors over time and the capabilities that stakeholders require to facilitate this interplay to support the emerging sectors of the future. With reference to the 3D printing industry, increasing numbers of direct and indirect stakeholders are being attracted into the ecosystem that is fostering and facilitating experimentation within the business models that are being explored. Experimentation is necessary to address the dynamism and complexity inherent in new technology markets, as there is little consensus on what capabilities are required to facilitate the formation of the business model or its eventual configuration.

A research framework, as shown in Figure 2, summarizes the arguments presented with reference to the 3D printing industry its, business models and ecosystems. This takes a process view with reference to the development of industry business models and identifies three stages: initiation, execution and extension. The framework also recognises the contribution of different capabilities to facilitate the development of the business model, namely, scalability, flexibility and extensibility, arising from the analysis of data presented in Section 3 and 4 of this paper. Furthermore, it is proposed that the ecosystem, product, platform or some combination will form an integral part of business model development.

Insert Figure 2 here 


\section{Methodology}

This research has adopted a theory building philosophy and employs a case study method (Eisenhardt 1989, Yin 2008, Ozcan and Eisenhardt 2009, Rong and Shi 2014) in light of the limited work that has been undertaken into business models and business ecosystems. This approach is also apposite in situations where a process view is undertaken.

\subsection{Empirical Setting}

To enhance our understanding of the sector, to provide context to the current business environment and to assist with the identification of key companies, the research began with three expert interviews with leading academics from the UK and China. These individuals have y arehave been engageding in the 3D printing industryies over for many years and shared their ideas with reference to the development of business models in the sector $3 D$ printing industries. $\underline{\text { Reflecting }}$ upon After these interviews discussions, it was concluded that we came up with some preliminary findings that the sector was dominated by three typical business models. The first sells 3D printers, and companies developing this model are typically very large firms that have been an early adopter of the technology (for example, 'Stratasys' and 'Tiertime') or more latecomers as entrepreneurial companies that entered later to exploit an opportunity created the sector as 3D technologies became open source within the sector (for example, 'Formlabs' and 'ZEEGINE'). The second is a platform business model providing a $3 \mathrm{D}$ printing service (for example, 'isodo3d', 'XYZ' and 'NJX'. While The company of $\mathrm{XYZ}$ is the sales agent for many big companies such ase.g. Stratasys, however it remains an is independent from them). A third and emerging model 
is some combination of product and platform, which has evolved in response to the fact that market demand has, as yet, did-not meet forecasts. A good example is the move by 'Stratasys' into desktop 3D printers and on-line 3D design communities through its acquisition of 'MakerBot' and its associated company 'Thingverse'.

As a result of these discussions, seven case companies were selected from three countries including USA, China and UK (see Tables 1 and 2). These cases cover all identified business models, ensuring the research has both construct validity and external validity (Gibbert et al., 2008).

Insert Table 1 here

Insert Table 2 here

\subsection{Data Collection}

Data was collected using the following protocols. All interviews were conducted with the key project manager/CEO who was entirely familiar with the development of the company's business model and the business ecosystem that supported this model (see Table 1). The researchers also participated in public events held by the seven companies which facilitated connections with their partners within the ecosystem, and secondary data was collected from exhibition catalogues and archival documents (see Table 3). By following these protocols, 
triangulation of the data was possible, increasing the reliability of the findings presented (Gibbert et al., 2008).

Insert Table 3 here

The interview protocol employed with respondents is shown in Table 4 and is divided into 3 sections. Section one provides contextual information; section two investigates the business model adopted by the company, how it has evolved and how it creates and appropriates value. The final Ssection three-analyses the interviewee's perception of the business ecosystem in which the company is embedded and how this ecosystem has supported the evolution of the business model.

Insert Table 4 here

\subsection{Data Analysis}

The data analysis went through four key techniques: coding (Auerbach and Silverstein, 2003), road mapping (Phaal et al., 2004), process mapping (Platts, 1993), and integration (Ozcan and Eisenhardt, 2009; Cusumano et al., 2015). In order to ensure the robustness of the research results, each author analysed and coded the data independently, these were then shared and and then-compared the results-collectively. To understand the process of business model development, respondents were asked to identify key milestone activities, reflect on the logic that informed activity at the time and identify any linkages to other 
stakeholders deemed important (Platts, 1993; Phaal et al., 2004). As a result of this work, three stages of development, namely, 'Initiation', 'Execution' and 'Extension', are proposed.

After identifying these stages, the data were coded for further analysis following the research framework shown in Figure 2. Two coding techniques were employed. Firstly, we organised the data into broad categories that explained how business operated and how value was created. Examples including 'incubating complementary stakeholders', 'product to new product' and 'product to platform' were identified and noted down. Secondly, these first order codes were narrowed down to identify relationships and integrate them into higher order codes. These higher order codes were used in the analysis to draw out the capabilities, identified as 'scalability', 'flexibility' and 'extensibility' that underpin the development of each business model at different stages of its life-cycle. This was followed by a process of integration (Ozcan and Eisenhardt, 2009) to provide a diagrammatical representation (shown in Figure 3) of the constructs relationship and the relationship between stages, capabilities and ecosystem structures.

Insert Figure 3 here

\section{Findings}

Following the research methodology, we have mapped out the evolutionary business model adopted by the seven case companies as shown in Figure 4. The vertical axis identifies the three typical business models and the companies 
associated with these models. The horizontal axis identifies the three stages through which the models develop (initiation, execution and extension), and provides examples of the processes that are being undertaken within these stages by the identified companies.

As shown in By learning form Figure 4, firms within the 3D printing sector we can see the focal cases-started out trying to pursue a range of with-different patterns of business models (namely product, platform or combination). Over time these The-business models, reflecting changes in the business environment, have patterns willevolved alongside, and with the support of, with the support efthe prevailing business ecosystems. The process of evolution can be most clearly observed in the cases of Zeegine and XYZ. As a result, during the three stages (initiation, execution and extension), some cases' business models have evolved into the others, the main trend is evolving to the combination business models. For example, the Zeegine started with product-based business models and evolved into platform-based in the second stage and finally enter combined business models. The company of XYZ also-started from platform-based business model and finally enter combined one.

\section{Insert Figure 4 here}

Comment [d2]: For whatever reason figure 4 does not fully reveal itself on my document and this is a problem when trying to follow the explanation

\subsection{Business Ecosystem Structure}

A product based ecosystem evolves (see Figure 4) to produce key products to end-users and it is incumbent upon focal firms to organize a supply chain based industrial system to create an efficient and effective means of production. 
'Tiertime' is a focal firm that provides a good example of a product based ecosystem; since the expiry of IP licences in the field of 3D printing, 'Tiertime' Comment [d3]: Do you want a date/timeframe here? has organized the assembly and supply of 3D printers to end users. 'Tiertime' spun-out of Tsinghua University and experimented with the development of industry level 3D printers. After finding that the market was too competitive and dominated by large western companies like 'Stratasys', they moved on to the development of desktop printers, where they were able to take advantage of the low production costs prevalent in China. The CEO indicated:

'the expiry of IP has reduced the entry barriers for small companies. We have developed our own hardware and software, and assemble our 3D printers at our manufacturing plant in Beijing. Being able to develop and build our 3D printers in China with the help of partners brings significant cost savings and we are able to target markets where cost, speed and flexibility are more important in the decision to buy than precision and quality'.

'Formlabs' is another example of a focal firm that only produces 3D printers, and has established a quick response supply chainwith quick responses.

... 'most of our key suppliers are based in the USA. We have calculated the cost of outsourcing and found it was efficient and provided cost-savings to manufacture in America.'

These examples help to highlight that the product-based ecosystem is normally organized by a focal firm that will outsource some parts of 3D printers and organize a supply-chain based ecosystem. While focal firms remain important key-within a platform based ecosystem, they have less influence and control, and 
the organisation of the ecosystem is more democratic based upon the interaction of partners within the platform.

[...] we tried our best to explore the potential demand, and to see if our company could meet those needs or whether we would need to find other suppliers that could help. [...]For example, we have found some potential demand within schools, so we approach them and discovered that they not only required the 3D printers but also a total solution for a 3D printing course. Then we acted as a platform to integrate our suppliers to develop a 3D printing text book that worked alongside the $3 D$ printers that were provided - offering a total solution to schools [...]' (CEO 'NJX'). This point was also addressed by the CEO of 'Isodo3D' in Southampton, 'we are a service platform; we build more demand by showcasing what we can do and educating customers. For example, a successful partnership was formed with a hospital that has produced a model of a kidney to facilitate a surgical process. This was highlighted on a BBC programme and has led to other potential partners coming forward. [...] In other situations we have provided information and examples of design prototypes that have been printed for shoes'

As indicated, 3D printing is still an emerging industry and the market demand, although promising, remains uncertain. Consequently some large firms, for example 'Stratasys' ${ }_{2}$ have also nurtured a mixed business ecosystem structure and recently acquired the desktop 3D printer company- 'MakerBot' whose CEO commented after the takeover 'we are aiming to set up a 3D printing ecosystem which is expansive, combining thousands of ecosystem stakeholders. [they are hardware and accessories, filaments, apps, solutions, people, design and models]. On our on-line platform, Thingiverse, last quarter we had 12 million downloads of 
our models; we aim to gradually establish this platform and through that significantly increase our sales of 3D printers.'

'Formlabs' also identified the limited demand for 3D printers as a cause for concern and suggested that it was time tothey were now considering a move to a platform based business to take advantage of their expertise in SLA (Stereolithography) technology.

This strategy is promising for the 3D printing sector as a whole as it is likely to stimulate both supply and demand within the sector and enhance the network effects that can evolve from the interaction within the market.

Hence we have the following proposition:

Proposition 1: In the 3D printing industry, there are three typical ecosystem structures, namely product based, platform based and an emerging system that is a combination of the two.

\subsection{Business Model Development and Capabilities}

As indicated above, the development process of a business model has been neglected by the extant literature (Chesbrough, 2007; Sanchez and Ricart, 2010; Amit and Zott, 2012). This paper addresses this gap and the analysis below, drawn from seven cases, suggests that business ecosystems have a substantial impact on business model development as shown in Figure 4. While the extant literature has tended to focus upon the execution of the business model (REFS?), $\underline{w} W e$ take a more detailed approach and suggest building a more holistic understanding of the process incorporating propose that business models are developed through a three stage process - 'initiation', 'execution' and 'extension': -with the extant literature emphasising stage two, 'execution'. Findings from 
our discussions also indicate that certain capabilities are necessary to facilitate this developmental process, identified as scalability, flexibility and extensibility.

\section{Stage one: Initiation}

Before business model execution can be attained, focal firms have to communicate with ecosystem partners to formulate a scalable business model. At this early stage, the focal firms within a business ecosystem tend to share their vision of a future business model and encourage ecosystem stakeholders to work together and contribute complementary resources (Reid and De Brentani, 2010; Reid and Brentani, 2012). This period is typified by a process of exploration, and various formulas may be tried and tested before a scalable model is executed. Scalability refers to a company's capability to convince stakeholders that the value creation and value appropriation strategies established within the business model represent a 'good deal' for all parties, and thus foster close and positive working relations within the network.

Establishing scalability within a platform based ecosystem is often regarded as more complex as it is likely to contain a larger number of relevant stakeholders that require careful management by the focal firm. However, it can also produce more business model permutations to build value creation and value appropriation opportunities. The role of experimentation, within this context, is therefore embedded in the initiation stage of a business model and is highlighted in the comments from three respondents.

[...] we started as an on-line social community to encourage other stakeholders to share their 3D printing design and manufacturing experience. [...] the knowledge and skills we accumulated over time from this became valuable and customers 
were keen for us to share our experience through training sessions [...], in these sessions we worked with partners to help them design and manufacture 3D models. Our business model evolved from this process and included the sale of printers and commissions from our model designs' (CEO of 'NJX').

\section{[...] we created a 3D printing platform and approached different stakeholders to} identify scalable business models. Our aim was to connect with the producers of large 3D printers hoping to convince them that we would be a good agent. At the same time we also evaluated the provision of a manufacturing service that offered a complete solution that included 3D scanning, 3D manufacturing and delivery. The latter option has already produced some success, for example, the surgery organism printing service in the healthcare industry.' (CEO 'Isodo3D')

The CEO from 'XYZ' also shared similar experiences; 'engaging in a platform based business model has allowed us to consider more scalable business opportunities. Taking the dental industry as an example, as 3D model designers our company was instrumental in bringing together manufacturing service companies and dental clinics. As a group we are now collectively working together in the production of dental implants. [...] in the near future, we also hope to connect with related sectors'

The product-based ecosystem often consists of fewer stakeholders. While focal firms are rarely in a position to dictate the business model, they are in a strong bargaining position when it comes to experimentation and development of a scalable business model. It is their vision and effort which helps to unite other stakeholders around the value creation and appropriation concepts that they have identified. The final outcome is normally some function of the relative 
power ascribed to focal firms, the degree to which other stakeholders have 'bought in' to the proposed value creation and appropriation model and market demand. 'Stratasys' is an example of a companyies that started within a product based ecosystem. Regarded as a first movers in the sector, they set out to exploit their considerable technological know-how in the development and manufacture of 3D printers. On the basis of an extensive evaluation of the new market, discussions with stakeholders and their own understanding of the potential of 3D printers, 'Stratasys' chose to produce and sell industry-level 3D printers. Other companies, for example 'ZEEGINE', entered after 3D technologies had become open source and they had the opportunity to learn from the market and the stakeholder environment as it developed; as a result 'ZEEGINE' focused on the desktop 3D printer market. This leads to the second proposition:

Proposition 2: during the initiation stage, it will be more feasible for platform based ecosystems to amalgamate around a business model than product based ecosystems.

\section{Stage two: Execution}

Execution suggests that a developed business model will support value creation and value appropriation, and stakeholders within the ecosystem are working towards some standardisation around that model. As a consequence, fine-tuning will still be taking place to 'balance' value distribution; this notion of 'balance' is a highly bespoke activity where stakeholders within the ecosystem are sometimes encouraged and on other occasions coerced into being flexible in sharing the value created and appropriated by the business model. The term 
'flexibility' refers to the ability to fine-tune the business model, to adjust the value creation and value appropriation dimensions between existing partners and, possibly, also the inclusion of new partners in response to internal and external changes.

In these relatively early stages of the industry, two business models, the production and sale of printers and a 3D manufacturing service, have evolved. A third business model is an assimilation of the first two models and is based on company's adaptation in response to experiential learning.

\section{Production and sale of 3D printers:}

As indicated, 'Formlabs', 'Stratasys', 'Tiertime' and 'ZEEGINE' have all been involved in the manufacture and sale of printers; in the case of some companies 'Stratasys' they were first movers in the industry while others 'ZEEGINE' have entered after relevant IP licences expire. The production and sale of printers operates within a product-based ecosystem where focal firms have considerable power and influence. This is because there are fewer stakeholders, and often because they have proprietary knowledge related to the new technology. The relative power and control of focal firms increases the flexibility of the model but also highlights the weak position that non-focal firms must contend with in product based ecosystems.

'[...] so far we have developed several generations of products, which closely reflect the market; our partners are happy to support some change to the approach if this helps to maintain revenues and thus far we have had some success with the model because we have correctly assessed potential demand.' (CEO of 'ZEEGINE') 
'we believe our ability to respond quickly to changes in the environment keeps us competitive. We maintain a very close watch on consumer preferences and we have the technological know-how to produce the type of printer the market demands. We are committed to the manufacture of printers but we are not fastened to a specific type of product'. (CEO of 'Tiertime')

These comments obscure some concerns in the industry with reference to the take up of 3D printing and the weaker than expected market demand.

'Stratasys', for example, are facing some difficulties in making the business model scalable within the product based ecosystem and 'ZEEGINE' have expressed similar concerns.

I believe Stratasys has not clearly identified their demand and the product based business will experience a decline as current sales capacity has already outstripped demand. There needs to be more thought given as to how market demand can be grown in the future' (CEO of 'XYZ', agent for 'Stratasys')

'we started by only selling desktop 3D printers but once the IP expired the market became overly competitive and the product based business [ecosystem] became very difficult. We focused on the provision of further services through the development of an on-line platform to increase the perceived value to our products' (CEO of 'ZEEGINE').

\section{A 3D manufacturing printing service}

The provision of a 3D manufacturing printing service is undertaken within a platform based eco-system. Such an ecosystem often exhibits lower levels of control by focal firms, a greater number of stakeholders and, as a result, increased complexity. In these complex scenarios, the response is often to 
implement more formal structures, agreements, processes and channels of communication that limit flexibility, in particular, the speed with which any finetuning can be implemented. This time lag between the need to be flexible and the ability to make the change can easily destabilise the incumbent business model. Hence, once established, platform based ecosystems often become more rigid and less likely to alter.

'it is not very easy to make the business model flexible based on the current platform because we have lots of stakeholders and we try to make them all happy with our service. We are trying to introduce more flexibility but it is being resisted.' (CEO of ' $\left.N J X^{\prime}\right)$

'Actually many model designers do not have to own a printer which will cost them too much if they do not often use it. So currently, many on-line printing service platforms have been launched including us to feed that market. We have to invest on many printers available for customers; they just pay a small amount to make the order on-line. Since we had invested a lot, we have to keep this type of business and lack of flexibility, [...] but anyway, we think of extending our platform based business by including more types of business. So I will attend different networking events and seminars to introduce our business [...]' (CEO of 'Isodo3D')

This leads to the next proposition.

Proposition 3: during the execution stage, product based ecosystems are likely to have a more flexible business model compared to platform based ecosystems. 


\section{Stage three- Extension}

This stage concerns the evolution of the business model after value creation and appropriation have been established. The dynamic nature of business models will need regular fine-tuning but certain exogenous and endogenous change will require more fundamental adjustments. In essence, the business model is extended to improve sustainability by adaption to new parameters as the result of change in the competitive environment, including process innovations that occur as the technology is deployed. This is particularly pertinent within a sector like 3D printing where the ich is still maturing, technology continues to is developing, new markets are being created and more companies and therefore competition is being attracted into the sector.

\section{A Mixed Product/Platform Business Model}

As indicated the take up of 3D printing has not resulted in the market size expected and there is concern in the industry about the sustainability of business models that focus exclusively upon the production and sale of printers or the provision of a 3D printing service. These concerns are reflected in comments of the CEO of 'NJX' that highlighted the 'considerable uncertainty within the industry around demand and the take up of the new technology'.

These concerns have led to a process of business model adaption by the firms studied. Those involved in the manufacture and sale of printers are attempting to raise awareness of the qualities and capabilities of 3D printing by involving themselves further down the supply chain. As indicated, 'Stratasys' has acquired the desktop 3D printer company 'MakerBot' and associated companies. After this takeover the CEO of 'MakerBot' commented. 
'we are aiming to set up a 3D printing ecosystem which is expansive, combining thousands of ecosystem stakeholders (from hardware and accessories, filaments, apps, solutions, design and modellers). On our on-line platform, Thingiverse, we have had 12 million downloads of our models in the last quarter and the aim is to gradually establish this platform and significantly increase our sales of $3 D$ printers.'

'ZEEGINE' are following a similar, if less expansive strategy: 'we aim to generate more demand through an on-line community to encourage interactions between parties - model designers, customers of our 3D printers and companies that have used a 3D printing service. By doing this we hope to extend our business model' ('ZEEGINE', COO)

Companies that have built a business model around the provision of a printing service are also looking for ways to increase demand for their products and ways to extend the business model. The CEO of 'Isodo3D' explained the efforts being made by the company to increase awareness of the potential of 3D printing 'we are a trying to build more demand by educating customers by showcasing product. For example, a successful project with a hospital that has culminated in the production of a model of a kidney to facilitate the process of surgery was recently highlighted on the BBC programme'.

The CEO of 'NJX' explained that they are experimenting with a number of options that would see the firm develop a platform where a broader section of stakeholders could be involved including material providers, designers, and other interested parties. While they are aware this has worked elsewhere they are concerned that 'there is insufficient demand in China to warrant this change.' 
Nevertheless there experiments continue 'as it is likely to be an option for the future.'

Proposition 4: during the extension stage, platform based ecosystems will exhibit greater adaption in business model development than that of product based ecosystem. This capability of extensibility would enable the original business model to involve more stakeholders, resources and ideas to renew the existing business model and improve sustainability.

\section{Discussion}

\subsection{Developing the 3D Printing Industry}

The 3D printing sector has considerable potential but it is at an immature stage and there are concerns about both the demand and supply in the market. In this context industrial practitioners are experimenting with scalable business models that either, sell 3D printers (product), provide a manufacturing service using 3D printers (platform), or provide a combination of both product and platform. However, this emerging industry lacks clarity and is yet to achieve sufficient scale to justify the significant investments. The inability to scale is directly related to building sufficient market demand that can effectively commercialise the 3D printing technologies. As a consequence the notions of value creation and appropriation are in a dynamic state.

This researcharticle highlights the importance of business ecosystems in the development of the 3D printing industry and how companies within this 
industry develop business models through an effective understanding and management of the business ecosystem throughout its lifecycle. Before a business model is established focal firms need to analyse the business ecosystems and associated stakeholders to understand how they can interact to contribute to its business model. While such analysis is important to offer detail on how they can contribute to value creation, it is also very useful in building a picture as to how value might be shared. As the model moves, through to the executable phase, there is also an opportunity for focal firms to create space for more ecosystem partners that can further extend their business models and introduce new value streams. In this way, the business model can be made more sustainable.

\section{By introducing three sequential stages; initiation, execution and extension this}

work This article-contributes to the dynamic process view of business models introducing three sequential stages; initiation, execution and extension and is This complements ary to the extant literature that mainstream business model research, which has examined the attributes of business models and their impact upon the causal relationship with-improvement ing the dimensions-of value creation and appropriation (Koh et al., 2005; Teece, 2010; Demil and Lecocq, 2010; McGrath, 2010; Amit and Zott, 2012; Baden-Fuller and Haefliger, 2013). While pPrevious literature has emphasised the execution stage and the factors that underpin value creation and value appropriation (Amit and Zott, 2001; Zott and Amit, 2007; Baden-Fuller and Haefliger, 2013) $\leftarrow$ Tthis paper investigates the process by which such business models evolve and the key capabilities scalability, flexibility and extensibility - that help to facilitate its evolution. As such the paper provides some insight into the methods and resources required 
to build effective business models by enabling positive interaction with associated business ecosystems.

We argue that, at initiation, there is considerable experimentation required to develop business models that are sufficiently scalable to deliver attributes of value creation and appropriation acceptable to a stakeholder group. In addition, we propose that focal firms, in the case of product ecosystems, are more dominant in directing the development of the business model but occupy a less dominant position in platform ecosystems due to the larger number of stakeholders. The resulting increase in complexity is often resolved through formal agreements that reduce the opportunity for experimentation.

Our empirical data points to a more fluid execution stage for business models. In the context of new technologies correctly identifying demand and routes to market is inherently difficult. While stakeholders do focus upon customer identification, customer engagement, value delivery, and monetization (BadenFuller and Haefliger, 2013), this is done within an environment that is difficult to predict and reliant upon a complex interplay of elements and stakeholders within the eco-system. In these contexts the execution stage is typically a dynamic process; focal firms have developed strategies with stakeholders to exploit an identified business model but this implementation stage is closely monitored. At this time Fflexibility is very important and at this stage. Iin some cases there is a is-requirement to fine-tune business models and strategies to reflect experiential learning within the ecosystem and exogenous change. In other cases flexibility is required to take on board the need for fundamental 
change and move on to more adaptive approach hange. The ecosystem in which the business model evolves influences the capability to be flexible. In product ecosystems flexibility is driven by a focal firm's awareness, of issues that impact upon the ability to create and appropriate value, and their ability to communicate and lead change. In platform eco-systems the recognition of a need for change is a more collective process based upon consensus among those firms involved. Focal firms can facilitate the process by raising awareness and offering suitable and acceptable alternatives but this can be a time consuming process that limits the speed of response. The willingness and ability to change becomes even more difficult to engender within both platforms when model adaptation is required.

In reviewing model adaptation, our research points to three business model extensions which are applicable to the 3D printing industry. These are:

Product to new products: The 3D printing industry has experienced some difficulties due to low levels of demand which has required some creative thinking among those involved in business models in this sector '[...]previously, we mainly focused on the industrial-level 3D printing machine, however, due to strong competition, in particular from Stratasys and 3D systems, we had to move our product line towards desktop 3D printers. The desktop $3 D$ printers have more customers and we were able to transfer the majority of our skill-sets to the new market which gave us some leverage as we entered the desktop market.' (CEO of 'Tiertime') 
A change from industrial to desktop printers alters the value creation and appropriation dimension of the business model. This is a more competitive market that is supported by open-source resources and customers eften-are often looking for more from than the 3D printer itself, for example access to design, materials and other expertise which needs to be available from the ecosystem. The value appropriation element will also change since the price of desktop printers will be significantly lower than those commanded by industrial level 3D printers. Focal firms within such business model extensions will therefore need to stimulate an increase in sales to maintain profit levels as profit per unit will fall.

Product to platform: in order to scale up the demand, a company may think of moving from the provision of the product to the provision of a platform where a printing service can be sold. 'ZEEGINE' is an interesting example. The company started out selling desktop 3D printers but found that the companies that bought the printers were underutilizing the resource. While this concerned the company they began to perceive an opportunity to establish an on-line platform to sell a printing service by making use of this excess capacity.

[...] we found out that many of the 3D printers sold to customers were underutilized and significant excess capacity was available when aggregated. Our idea was to establish an on-line platform, which all stakeholders, model designers, customers and printer owners could access. This created a communication channel which allowed stakeholders to cross sell to each other [ ... ] This addressed the problem of excess capacity, helped increase revenue for printers and provided an outlet for 
model designers and others to create product using the new 3D printing method.' (CEO of 'ZEEGINE')

Creating win-win scenarios of this nature has the potential to build strong networks among stakeholders (Rochet and Tirole, 2003; Zhu and Iansiti, 2012) and shows an innovative approach to the development of business models on behalf of the management team of 'ZEEGINE'

Platform to new platform: this type of business model extension introduces more platforms to enhance the original scope of the business model. For example 'MakerBot', the manufacturer of desktop 3D printers within 'Stratasys', has created an ecosystem with partners from apps development, hardware and accessories, design modellers and solutions; enhancing and strengthening the ecosystem in support of the business model. 'MakerBot' are also behind another platform via Thingiverse, which is an on-line database of 3D models that are open-sourced. This platform is based upon a partnership between Thingiverse and 3D hubs ${ }^{1}$, which enables the 3D models available on 'Thingverse' to be seamlessly printed via 3D hubs creating further value creation and appropriation.

In summary, the business models can be extended in three ways; product to new products, product to platform or platform to new platforms. The development of extensions to the business model indicate that emerging industries are paying more attention to broadening the range of stakeholders to generate greater network effects and speed up the commercialization of new technologies

\footnotetext{
1 http://www.castleink.com/category/6934/4.24.15\%3A-MakerBotThingiverse-and-3D-Hubs-Provides-Even-Better-Access-to-3DPrinting.html?language $=$ en
} 
(Kenney and Pon, 2011; Gawer and Cusumano, 2014; Rong et al., 2015a). This is particularly the case with business models supported by platform based ecosystem which already have more stakeholders and the capability to extend their current business model.

The findings therefore highlight the key importance of business ecosystems in helping organisations to build sustainable business models through the identification of value creation opportunities and the establishment of strategies that enable them to appropriate that value. This process also helps to build flexibility within established business models and to identify new opportunities that can extend the existing model. These findings could better equip those industrial practitioners with knowledge and strategies to gradually build up, scalable and profitable business models through a more effective understanding and management of relevant business ecosystems.

\section{Future research}

The paper has its limitations. F: firstly, though it demonstrates the relationship between business model dynamics and ecosystems, howeverthe dynamic process requires further exploration as is still not fully explored, there remains a lack of clarity relating to is still a gap about the determinants of business model dynamics $\div$ s Secondly, though a rigorous case study method was employed, we need more cases are required to verify theese three patterns of business model development, though we follow a rigorous case study sampling methods;

€Thirdly, this article has put forward four propositions that relate to the evolution of business models within the 3D printing industry and how they are 
integrated with the ecosystems of that industry. There is an opportunity for

future research to build upon this paper by testing these propositions within the 3D printing sector but also to investigate the degree to which such propositions

are generalizable in other emerging technology sectors $:$ Finallyfourthly,

regarding to the platform-based model, the determinants of network effect

between supplier and customers in 3D printing platform need further

exploration in order to understand how to trigger off such business model.

\section{Acknowledgement}

This research is supported by the National Natural Science Foundation of China (Grant no. 71402051), Beijing Excellent Talent training Program, the 'Innovation Method Fund of China' from Ministry of Science and Technology of China (MOST) under Project No. 2016IM010200, and 'Tang Young Scholar Awards', Tsinghua University Initiative Scientific Research Program No.2016THZWYY12. This work was also supported by the British Academy and the Society for the Advancement of Management Studies (SAMS) under Grant number SG140243;

\section{Reference:}

Adner, R., Kapoor, R., 2010. Innovation Ecosystems and the Pace of Substitution: Re-examining Technology S-curves (working paper). Tuck School of Business, Dartmouth College.

Amit, R., Zott, C., 2001. Value creation in e-business. Strategic management journal 22, 493-520.

Amit, R., Zott, C., 2012. Creating value through business model innovation. MIT Sloan Management Review 53, 41-49.

Auerbach, C.F., Silverstein, L.B., 2003. Qualitative data: An introduction to coding and analysis. NYU press.

Baden-Fuller, C., Haefliger, S., 2013. Business Models and Technological Innovation. Long Range Planning, Managing Business Models for Innovation, Strategic Change and Value Creation 46, 419-426.

Berman, B., 2012. 3-D printing: The new industrial revolution. Business Horizons $55,155-162$. 
Casadesus-Masanell, R., Ricart, J.E., 2010. From strategy to business models and onto tactics. Long range planning 43, 195-215.

Cavalcante, S., Kesting, P., Ulhøi, J., 2011. Business model dynamics and innovation:(re) establishing the missing linkages. Management decision 49, 1327-1342.

Chesbrough, H., 2007. Business model innovation: it's not just about technology anymore. Strategy \& leadership 35, 12-17.

Chesbrough, H., 2010. Business model innovation: opportunities and barriers. Long Range Planning 43, 354-363.

Chesbrough, H., 2012. Why companies should have open business models. MIT Sloan management review 48.

Cusumano, M.A., Kahl, S.J., Suarez, F.F., 2015. Services, industry evolution, and the competitive strategies of product firms. Strat. Mgmt. J. 36, 559-575.

Dahan, N.M., Doh, J.P., Oetzel, J., Yaziji, M., 2010. Corporate-NGO collaboration: Co-creating new business models for developing markets. Long range planning 43, 326-342.

de Vasconcelos Gomes, L.A., Facin, A.L.F., Salerno, M.S., Ikenami, R.K., 2016. Unpacking the innovation ecosystem construct: Evolution, gaps and trends. Technological Forecasting and Social Change.

Demil, B., Lecocq, X., 2010. Business model evolution: In search of dynamic consistency. Long Range Planning 43, 227-246.

Gawer, A., Cusumano, M.A., 2014. Industry Platforms and Ecosystem Innovation. J Prod Innov Manag 31, 417-433.

Gibbert, M., Ruigrok, W., Wicki, B., 2008. What passes as a rigorous case study? Strategic Management Journal 29, 1465-1474.

Hacklin, F., Wallnöfer, M., 2012. The business model in the practice of strategic decision making: insights from a case study. Management Decision 50, 166-188.

Iansiti, M., Levien, R., 2004. Strategy as ecology. Harvard Business Review 82, 68-81.

Inoue, Y., Tsujimoto, M., 2017. New market development of platform ecosystems: A case study of the Nintendo Wii. Technological Forecasting \& Social Change, in press.

Kenney, M., Pon, B., 2011. Structuring the Smartphone Industry: Is the Mobile Internet OS Platform the Key? Journal of Industry, Competition and Trade $11,1-23$.

Koh, S.C., Gunasekaran, A., Saad, S.M., 2005. A business model for uncertainty management. BENCHMARKING-BRADFORD- 12, 383.

Liu, G., Rong, K., 2015. The Nature of the Co-Evolutionary Process Complex Product Development in the Mobile Computing Industry's Business Ecosystem. Group \& Organization Management 40, 809-842.

Moore, J., 1993. Predators and prey: a new ecology of competition. Harvard Business Review 71, 75-86.

Moore, J., 2006. Business ecosystems and the view from the firm. Antitrust Bulletin 51, 31.

Osterwalder, A., Pigneur, Y., 2010. Business model generation: a handbook for visionaries, game changers, and challengers. John Wiley \& Sons. 
Ozcan, P., Eisenhardt, K.M., 2009. Origin of alliance portfolios: Entrepreneurs, network strategies, and firm performance. Academy of Management Journal 52, 246-279.

Petrovic, V., Vicente Haro Gonzalez, J., Jorda Ferrando, O., Delgado Gordillo, J., Ramon Blasco Puchades, J., Portoles Grinan, L., 2011. Additive layered manufacturing: sectors of industrial application shown through case studies. International Journal of Production Research 49, 1061-1079.

Phaal, R., Farrukh, C.J.., Probert, D.R., 2004. Technology roadmapping-A planning framework for evolution and revolution. Technological Forecasting and Social Change 71, 5-26.

Platts, K.W., 1993. A Process Approach to Researching Manufacturing Strategynull. Int Jrnl of Op \& Prod Mnagemnt 13, 4-17.

Rochet, J.-C., Tirole, J., 2003. Platform competition in two-sided markets. Journal of the European Economic Association 1, 990-1029.

Rong, K., Hou, J., Shi, Y., Lu, Q., 2010. From Value Chain, Supply Network, Towards Business Ecosystem (BE): Evaluating the BE concept implications to emerging industrial demand. Presented at the The IEEE International Conference on Industrial Engineering and Engineering Management, Dec. 7-10, 2010, Macau, China.

Rong, K., Hu, G., Lin, Y., Shi, Y., Guo, L., 2015a. Understanding business ecosystem using a $6 \mathrm{C}$ framework in Internet-of-Things-based sectors. International Journal of Production Economics 159, 41-55.

Rong, K., Wu, J., Shi, Y., Guo, L., 2015b. Nurturing business ecosystems for growth in a foreign market: Incubating, identifying and integrating stakeholders. Journal of International Management 21, 293-308.

Sanchez, P., Ricart, J.E., 2010. Business model innovation and sources of value creation in low-income markets. European management review 7, 138154.

Sandström, C.G., 2015. The non-disruptive emergence of an ecosystem for 3D Printing-Insights from the hearing aid industry's transition 1989-2008. Technological Forecasting and Social Change.

Teece, D.J., 2010. Business models, business strategy and innovation. Long Range Planning 43, 172-194.

van Putten, B.-J., Schief, M., 2013. The relation between dynamic business models and business cases. In: Supporting Reuse in Business Case Development. Springer, pp. 118-133.

Viswanadham, N., Samvedi, A., 2013. Supplier selection based on supply chain ecosystem, performance and risk criteria. International Journal of Production Research 51, 6484-6498.

West, J., Kuk, G., 2016. The complementarity of openness: How MakerBot leveraged Thingiverse in 3D printing. Technological Forecasting and Social Change 102, 169-181.

Zhu, F., Iansiti, M., 2012. Entry into platform-based markets. Strategic Management Journal 33, 88-106.

Zott, C., Amit, R., 2007. Business model design and the performance of entrepreneurial firms. Organization Science 18, 181-199.

Zott, C., Amit, R., 2010. Business model design: an activity system perspective. Long range planning $43,216-226$. 
Zott, C., Amit, R., Massa, L., 2011. The business model: recent developments and future research. Journal of management 37, 1019-1042. 


\section{Figure}

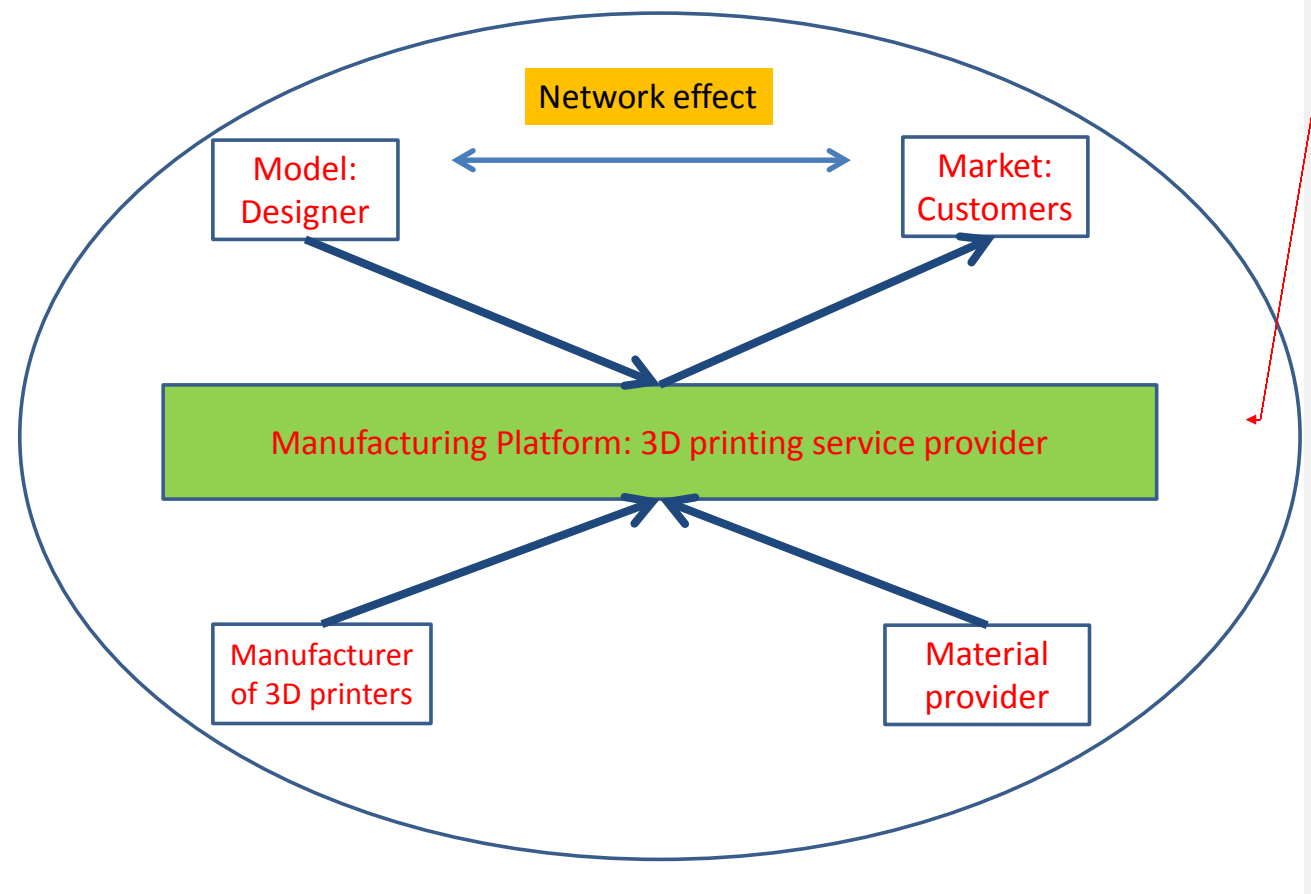

Formatted: Heading 1, Left, Space

Before: 0 pt, After: 0 pt, Line

spacing: single

Figure 1: Business ecosystems of 3D printing industry

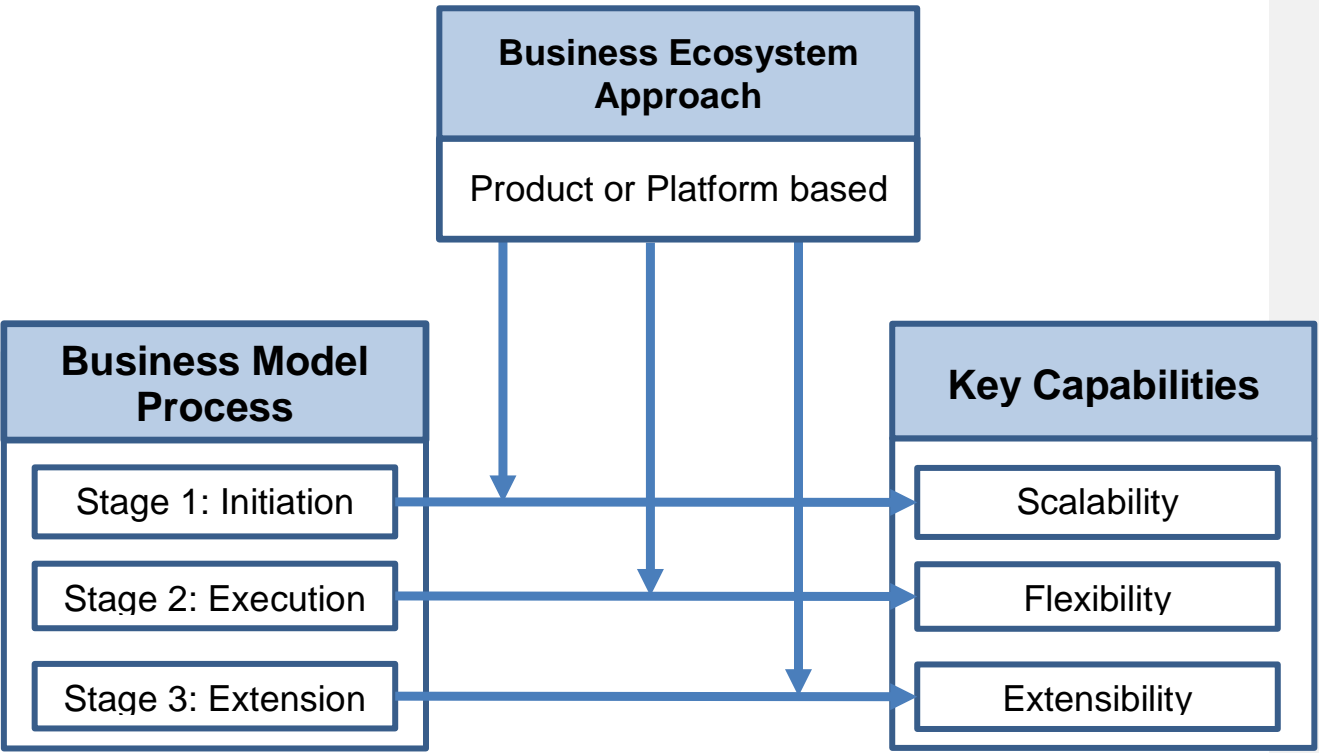


Figure 2: Research Framework
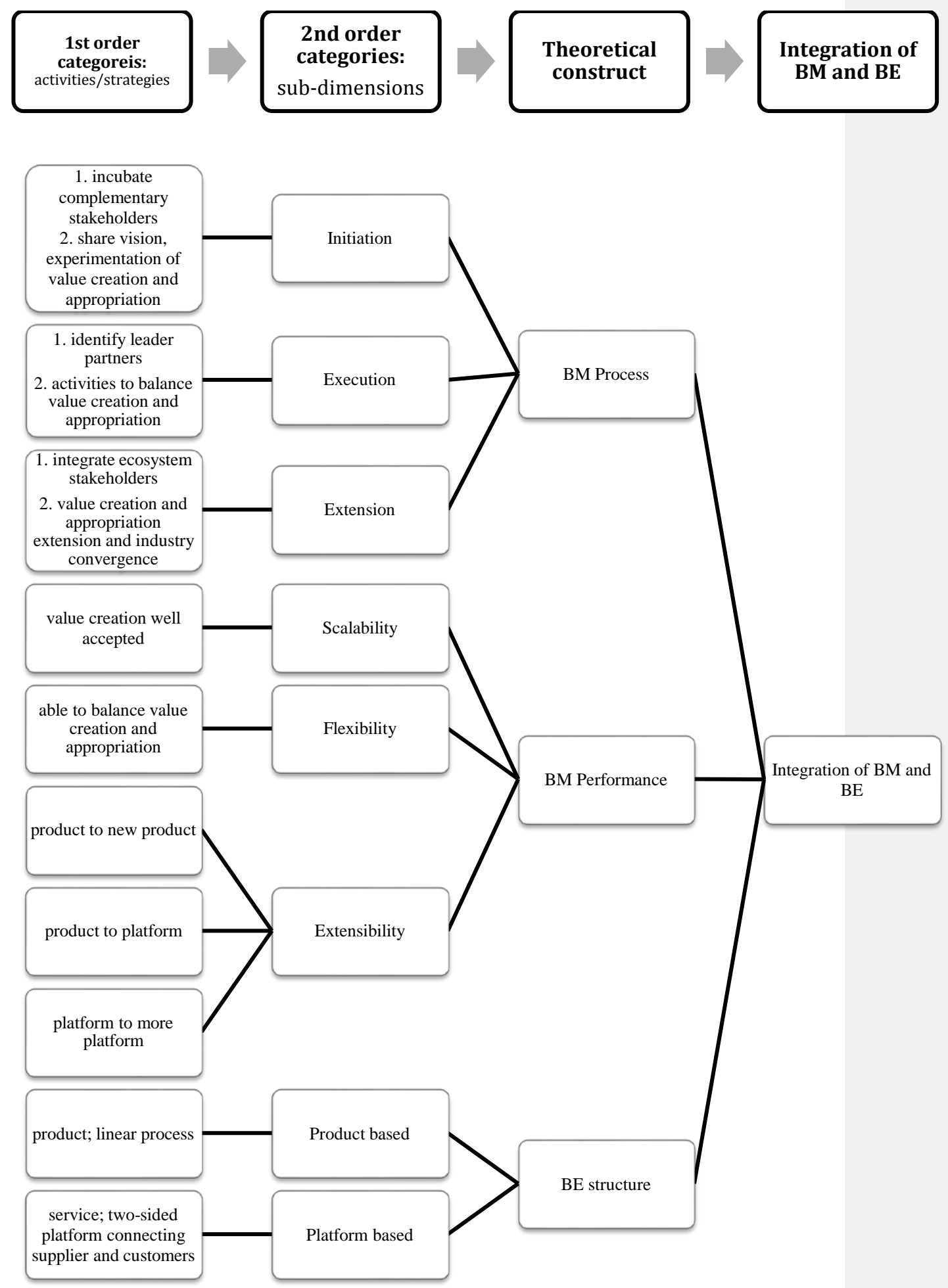
Figure 3: Maps of coding 


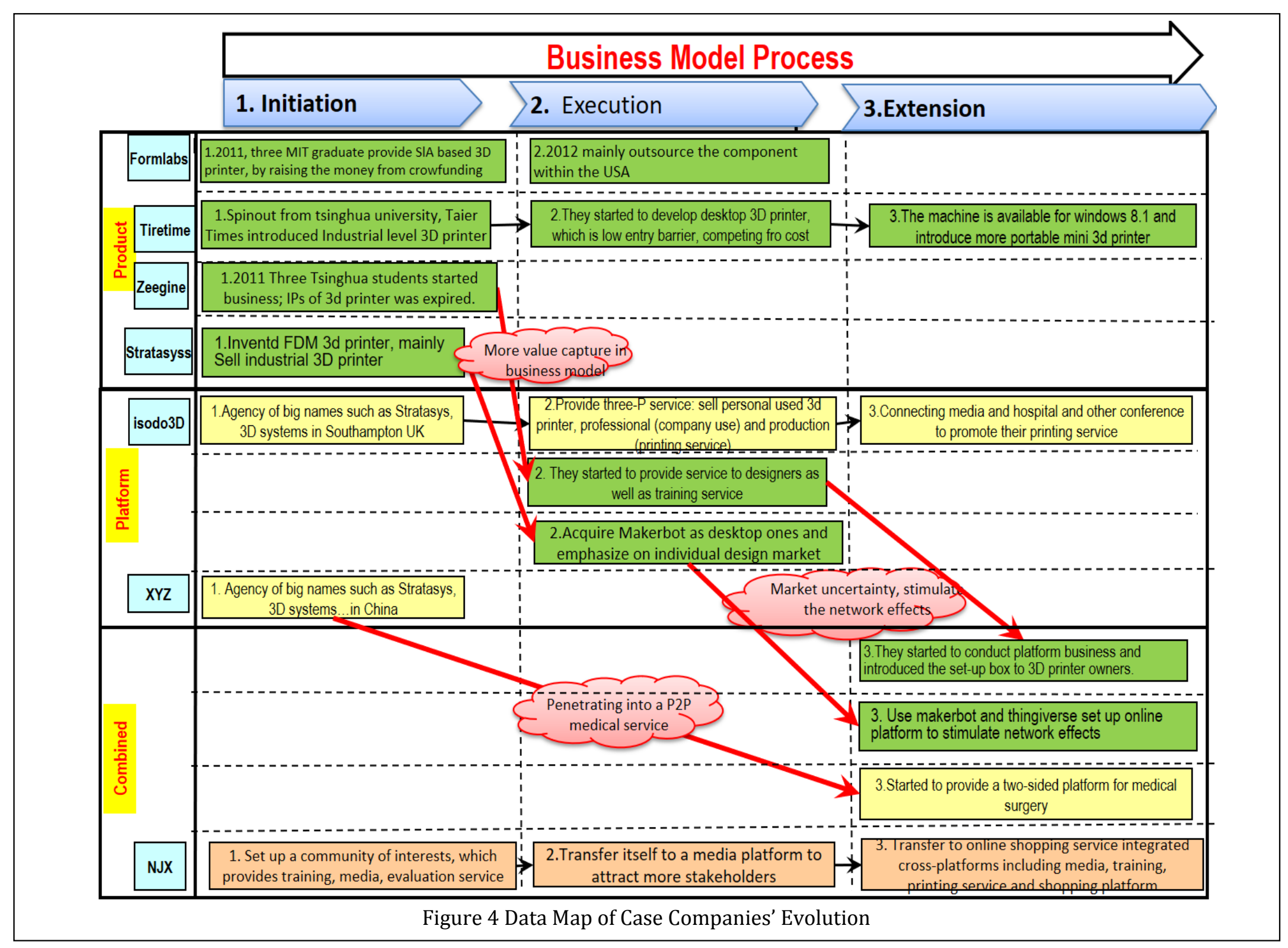




\section{Tables}

Table 1: Overview of 3D Printer Companies Interviewed

\begin{tabular}{|c|c|c|c|c|c|c|c|c|}
\hline & Location & Established & $\begin{array}{l}\text { Ecosystem } \\
\text { structure }\end{array}$ & $\begin{array}{l}\text { Interviewee } \\
\text { (hours) }\end{array}$ & $\begin{array}{l}\text { Phone/ Email/ } \\
\text { Wechat/ skype }\end{array}$ & Conference & $\begin{array}{l}\text { Documents, } \\
\text { see table } \\
\text { below }\end{array}$ & Expert Interview \\
\hline $\begin{array}{l}\text { Case } \\
\text { 1:ZEEGINE }\end{array}$ & Beijing, China & 2013 & $\begin{array}{l}\text { Product based: } \\
\text { 3D printer }\end{array}$ & $\begin{array}{l}\text { CEO(2 hours) , } \\
\text { Marketing } \\
\text { director (2 } \\
\text { hours), COO (2 } \\
\text { hours) }\end{array}$ & $\begin{array}{l}\text { Regularly } \\
\text { wechat } \\
\text { commuincation }\end{array}$ & & $\begin{array}{l}\text { youtube } \\
\text { Video, } \\
\text { documents }\end{array}$ & \multirow{7}{*}{$\begin{array}{l}\text { One Professor from } \\
\text { China Academy of } \\
\text { Science, one Professor } \\
\text { University of } \\
\text { Cambridge; one } \\
\text { professor from } \\
\text { University of Science } \\
\text { and Technology of } \\
\text { China }\end{array}$} \\
\hline $\begin{array}{l}\text { Case 2: } \\
\text { Formlabs }\end{array}$ & Boston, USA & 2011 & $\begin{array}{l}\text { Product based: } \\
\text { 3D printer }\end{array}$ & $\begin{array}{l}\text { Director of Asian } \\
\text { Sales ( } 2 \text { hours) }\end{array}$ & Email follows up & & $\begin{array}{l}\text { video, } \\
\text { documents }\end{array}$ & \\
\hline $\begin{array}{l}\text { Case 3: } \\
\text { 'Tiertime' }\end{array}$ & Beijing, China & 2001 & $\begin{array}{l}\text { Product based: } \\
\text { 3D printer }\end{array}$ & CEO (2 hours) & Phone call & & Documents & \\
\hline $\begin{array}{l}\text { Case 4: } \\
\text { isodo3D }\end{array}$ & $\begin{array}{l}\text { Southampton, } \\
\text { UK }\end{array}$ & 2012 & $\begin{array}{l}\text { Platform } \\
\text { based: 3D } \\
\text { printer agency }\end{array}$ & CEO (2 hours) & Emails follow up & $\begin{array}{l}15 \text { May 2015, } \\
\text { whole day } \\
\text { seminar }\end{array}$ & Documents & \\
\hline Case 5: NJX & Beijing, China & 2010 & $\begin{array}{l}\text { Platform } \\
\text { based: 3D } \\
\text { printer media }\end{array}$ & CEO (2 hours) & $\begin{array}{l}\text { Wechat } \\
\text { communication }\end{array}$ & & $\begin{array}{l}\text { Documents, } \\
\text { sample } \\
\text { projects }\end{array}$ & \\
\hline $\begin{array}{l}\text { Case 6: An } \\
\text { anonymous } \\
\text { agent-XYZ }\end{array}$ & Beijing, China & 2013 & $\begin{array}{l}\text { Platform } \\
\text { based: } \\
\text { manufacturing }\end{array}$ & CEO (6 hours) & $\begin{array}{l}\text { Wechat } \\
\text { communication }\end{array}$ & & Documents & \\
\hline $\begin{array}{l}\text { Case 7: } \\
\text { Stratasys }\end{array}$ & $\begin{array}{l}\text { Shanghai, } \\
\text { China }\end{array}$ & 1980 & $\begin{array}{l}\text { Mixed of } \\
\text { product and } \\
\text { platform based }\end{array}$ & $\begin{array}{l}\text { Conference with } \\
\text { CEO China of } \\
\text { Stratasys, CEO of } \\
\text { MakerBot, } \\
\text { marketing } \\
\text { director (4 }\end{array}$ & Linked-in & $\begin{array}{l}\text { Shanghai } \\
\text { Stratasys whole } \\
\text { conference } \\
\text { including } \\
\text { Makerbot CEO, } \\
\text { Thingiverse and }\end{array}$ & $\begin{array}{l}\text { Youtube; } \\
\text { white } \\
\text { papers }\end{array}$ & \\
\hline
\end{tabular}




\begin{tabular}{|l|l|l|l|l|l|l|l|l|}
\hline & & & & hours $)$ & & $\begin{array}{l}\text { Stratasys Chinese } \\
\text { CEO }\end{array}$ & & \\
\hline
\end{tabular}

Table 2 The position of case firms in the 3D printing ecosystem

\begin{tabular}{|l|l|l|l|l|l|}
\hline & Hardware vendor & Selling agent & $\begin{array}{l}\text { Manufacturing (3D } \\
\text { printing service } \\
\text { provider) }\end{array}$ & $\begin{array}{l}\text { Community } \\
\text { (developers and } \\
\text { customers) }\end{array}$ & Others: Media \\
\hline Formlabs & & & & & \\
\hline Stratasys & & & & \\
\hline 'Tiertime' & & & & \\
\hline ZEEGINE & & & & \\
\hline Isodo3D & & & & & \\
\hline XYZ & & & & & \\
\hline NJX & & & & & \\
\hline
\end{tabular}


Table 3: Secondary data evidence

\begin{tabular}{|c|c|}
\hline & Stratasys documents and video \\
\hline $\begin{array}{l}\text { Stratasys/ makerbot } \\
\text { ecosystem }\end{array}$ & $\begin{array}{c}\text { Makerbot evolution slides: } \\
\text { http://www.slideshare.net/burtonlee1/axel-hafner-maker-bot-europe-european-market-entry-stanford-engineering-feb- } \\
\underline{2-2015}\end{array}$ \\
\hline $\begin{array}{c}\text { Strasys/ makerbot } \\
\text { overview }\end{array}$ & http://www.sec.gov/Archives/edgar/data/1517396/000110465913050451/a13-15347_1ex99d3.htm \\
\hline $\begin{array}{l}\text { Makerbot, digitizer- } \\
\text { 3D scanner }\end{array}$ & http://www.makerbot.com/products \\
\hline $\begin{array}{c}\text { Community of } \\
\text { developers }\end{array}$ & https://www.thingiverse.com/about/ \\
\hline $\begin{array}{l}\text { Stratasys white papers } \\
\text { on 3D printing } \\
\text { industry }\end{array}$ & http://www.stratasys.com/resources/white-papers/3d-printing-now-and-beyond \\
\hline Stratasys official video & https://www.youtube.com/user/ObjetGeometries/featured \\
\hline \multirow[t]{2}{*}{$\begin{array}{l}\text { Makerbot official } \\
\text { video: for educator, } \\
\text { designer and } \\
\text { ecosystem }\end{array}$} & https://www.youtube.com/channel/UCj9shDwDhuw5omMrH0o9IcQ \\
\hline & ZEEGINE documents and video \\
\hline ZEEGINE & http://www.zeegine.com/ \\
\hline $\begin{array}{l}\text { ZEEGINE education } \\
\text { activities }\end{array}$ & http://www.zeegine.com/zeeedu.html \\
\hline ZEEGINE hisotry & http://www.zeegine.com/about.html \\
\hline $\begin{array}{c}\text { The community of } \\
\text { ZEEGINE }\end{array}$ & http://www.dayinji.ren/index.html \\
\hline $\begin{array}{l}\text { ZEEGINE video on } \\
\text { interview CEO }\end{array}$ & $\begin{array}{l}\text { https://www.youtube.com/watch?v=dYiw79sD7U8 } \\
\text { https://www.youtube.com/watch?v=eqhST_RTYk }\end{array}$ \\
\hline
\end{tabular}




\begin{tabular}{|c|c|}
\hline $\begin{array}{l}\text { ZEEGINE video on } \\
\text { printing iphone case }\end{array}$ & https://www.youtube.com/watch?v=Fe-l8CYszNQ \\
\hline & Isodo3D documents and video \\
\hline About isodo3d & https://www.isodo3d.com/about-us/ \\
\hline $\begin{array}{l}22 \text { video about } \\
\text { Isodo3d }\end{array}$ & https://www.youtube.com/channel/UCU4TNnTV57nw]EbGqEql2zQ \\
\hline $\begin{array}{l}\text { BBC news about } \\
\text { isodo3d supporting } \\
\text { kidney surgery and } \\
\text { interview of CEO }\end{array}$ & $\begin{array}{l}\text { http://www.bbc.co.uk/news/uk-england-hampshire-30801273 } \\
\text { https://es-la.facebook.com/iSoDo3D/posts/811045019007368 }\end{array}$ \\
\hline Isodo3d document & https://www.isodo3d.com/cms/documents/Isodo3d\%20Brochure\%200515.pdf \\
\hline \multirow[t]{2}{*}{$\begin{array}{c}\text { Isodo3d's selling } \\
\text { product }\end{array}$} & https://www.isodo3d.com/cms/documents/Extruder_Jam_Repair 10-23-14.pdf \\
\hline & Tiertime \\
\hline Milestone of Tiertime & http://www.tiertime.com/about/milestones \\
\hline $\begin{array}{l}\text { Compare of its } \\
\text { products }\end{array}$ & http://www.tiertime.com/products/comparison \\
\hline $\begin{array}{l}\text { Tiertime: industrial, } \\
\text { desktop 3D printer, } \\
\text { software }\end{array}$ & http://www.tiertime.com/products \\
\hline $\begin{array}{c}\text { ‘Tiertime’ official } \\
\text { channel }\end{array}$ & https://www.youtube.com/channel/UCFuFhQw3YFGHBdoVJUrk69A/videos \\
\hline $\begin{array}{c}\text { Review of UP!- } \\
\text { desktop product of } \\
\text { Tiertime }\end{array}$ & https://www.youtube.com/watch?v=U9FMVjAEdzo \\
\hline UP box -the mini one & https://www.youtube.com/watch?v=UTiZ]isw9rU \\
\hline With windows 8.1 & https://www.youtube.com/watch?v=NiZA2mZQW2Y \\
\hline $\begin{array}{l}\text { Application case of } \\
\text { Tiertime }\end{array}$ & http://www.tiertime.com/case-study/3d-printed-mammoth-by-taiwan-national-science-and-technology-museum \\
\hline
\end{tabular}




\begin{tabular}{|c|c|}
\hline $\begin{array}{l}\text { Online sales at Taobao } \\
\text { and Jd.com }\end{array}$ & $\begin{array}{c}\text { https://tiertime.taobao.com/ } \\
\text { http://item.jd.com/1090775.html }\end{array}$ \\
\hline & Formlabs \\
\hline About Formlabs & http://formlabs.com/company/about-us/ \\
\hline Newest product & http://formlabs.com/products/3d-printers/form-2/ \\
\hline Techcrunch review & http://techcrunch.com/2015/12/02/the-formlabs-form-2-brings-the-3d-printing-magic-again/ \\
\hline $\begin{array}{c}\text { Formlabs official } 57 \\
\text { clips of video }\end{array}$ & https://www.youtube.com/user/formlabs1/videos?flow=grid\&view=57 \\
\hline \multirow[t]{2}{*}{$\begin{array}{l}\text { Documentary: Printing } \\
\text { the legend }\end{array}$} & https://www.netflix.com/gb/title/80005444?p=os \\
\hline & NJX \\
\hline Overview of NJX & http://www.nanjixiong.com/ \\
\hline $\begin{array}{l}\text { Developer community } \\
\text { of NJX }\end{array}$ & http://www.xiongwanyi.com/mobile/ \\
\hline $\begin{array}{l}\text { Review of mainstream } \\
\text { 3d printers }\end{array}$ & http://www.nanjixiong.com/forum-54-1.html \\
\hline $\begin{array}{c}\text { Forum and news } \\
\text { platform of NJX }\end{array}$ & http://www.nanjixiong.com/forum.php \\
\hline Online sales & https://shop114524200.taobao.com/ \\
\hline $\begin{array}{c}\text { Pancake-making 3d } \\
\text { printer }\end{array}$ & https://item.taobao.com/item.htm?spm=a1z10.1-c.w9294912-13063765360.4.CERWWz\&id=521719883610 \\
\hline $\begin{array}{c}8 \text { Online teaching } \\
\text { course by NJX in } \\
\text { Tencent education } \\
\text { platform } \\
\end{array}$ & https://ke.qq.com/teacher/530879319 \\
\hline NJX online video & $\underline{\text { http://i.youku.com/u/UMTUxNDEzMzM40A== }}$ \\
\hline & $\mathrm{XYZ}$ is confidential, not available to disclosure \\
\hline
\end{tabular}




\section{Table 4: Interview Protocol}

\begin{tabular}{|l|l|}
\hline Questions & Interviewee \\
\hline What is your company's background information? & \\
\hline Could you please introduce your company's background? & Director/CEO \\
\hline Could you introduce the product portfolio? & Director/CEO \\
\hline What is your job title? & Director/CEO \\
\hline & \\
\hline What is your company's business model & Director/CEO \\
\hline Could you briefly introduce your business models? & Director/CEO \\
\hline How does your business model be formulated? & Director/CEO \\
\hline How does your company create value for your products? & Director/CEO \\
\hline How does your company appropriate value? & Director/CEO \\
\hline Is your business model experienced change? & Director/CEO \\
\hline What's the key capability to ensure business model evolution? & \\
\hline & \\
\hline Interaction between business models and business ecosystems & $\begin{array}{l}\text { CEO/Director/project } \\
\text { manager }\end{array}$ \\
\hline Could you describe your business ecosystem/partners' network? & $\begin{array}{l}\text { CEO/Director/project } \\
\text { manager }\end{array}$ \\
\hline How those partners support your business model development? & $\begin{array}{l}\text { CEO/Director/project } \\
\text { manager }\end{array}$ \\
\hline $\begin{array}{l}\text { Could you categorize your direct or indirect partners and their } \\
\text { contribution to your business model development? }\end{array}$ & \\
\hline
\end{tabular}

